\title{
Logging Characteristics and Identification Methods of Low Resistivity Oil Layer: Upper Cretaceous of the Third Member of Qingshankou Formation, Daqingzijing Area, Songliao Basin, China
}

\author{
Congjun Feng, ${ }^{1,2}$ Murray Gingras, ${ }^{3}$ Mengsi Sun, ${ }^{1,2}$ and Bing Wang ${ }^{4}$ \\ ${ }^{1}$ State Key Laboratory of Continental Dynamics, Northwest University, Xian 710069, China \\ ${ }^{2}$ Department of Geology, Northwest University, Xian 710069, China \\ ${ }^{3}$ Earth \& Atmospheric Sciences, Faculty of Science, University of Alberta, Edmonton, AB, Canada T6G 2E3 \\ ${ }^{4}$ College of Geophysics and Information Engineering, China University of Petroleum, Beijing 102249, China \\ Correspondence should be addressed to Congjun Feng; fengcj@nwu.edu.cn
}

Received 13 February 2017; Accepted 27 April 2017; Published 29 May 2017

Academic Editor: Amgad Salama

Copyright (c) 2017 Congjun Feng et al. This is an open access article distributed under the Creative Commons Attribution License, which permits unrestricted use, distribution, and reproduction in any medium, provided the original work is properly cited.

\begin{abstract}
This study focuses on low resistivity thick layer sandstone in the X XII groups of the third member of Qingshankou Formation at Daqingzijing oilfield, along with comprehensive data of logging, core, oil test, and production test. Based on the current data, we characterized the logs of low resistivity thick-layer sandstone, quantitatively identified calcareous sandstone and low resistivity reservoir, predicted the reservoir thickness, and further explored the causes of low resistivity reservoir of the region. The resistivity of thick layer sandstone in the X XII groups of Qingshankou Formation can be classified into low amplitude logfacies, middle amplitude logfacies, and sharp high amplitude logfacies. Sharp high amplitude logfacies sandstone is the tight sandstone of the calcareous cementation. Low amplitude logfacies sandstone is water layer. For the middle amplitude logfacies sandstone, water layer or oil-water layer can be identified with the identification standard. Low amplitude structure, high clay content, high irreducible water saturation, and high formation water salinity are attributed to the origin of low resistivity oil layer.
\end{abstract}

\section{Introduction}

Songliao Basin is a large Mesozoic to Cenozoic hydrocarbonbearing sedimentary basin in Northeast China (Figure 1(a)), with a total area of about $260,000 \mathrm{~km}^{2}$. The basin is diamond shaped with its long axis oriented NNE. Six secondary structural units are present in the basin, including the central concave, the southwest uplift, the southeast uplift, the northeast uplift, the western slope, and the northern dip areas $[1,2]$. Previous studies showed that this basin is filled with continentally associated clastic strata, with multiple oilbearing layers, of which Cretaceous and Tertiary lacustrine units are the most important [3-6].

The Daqingzijing oilfield is located in the south central concave of Songliao Basin (Figure 1(b)). The overall structure is an asymmetric syncline with axial NNE direction that has a steeply dipping west limb and nearly horizontal east limb. It has a practical exploration area of $1500 \mathrm{~km}^{2}$ that possesses reserves of approximately 700 million barrels of crude oil. The main reservoir unit is the Cretaceous Qingshankou Formation wherein the depth of oil formation ranges from $1600 \mathrm{~m}$ to $2500 \mathrm{~m}$. The Qingshankou Formation is characterized by low porosity, low permeability, and low resistivity sandstone reservoirs [7]. Reservoir microfacies, resource distribution, and identification of low resistivity resource accumulations are urgent areas of research for this oilfield [7-10].

The identification and evaluation of low resistivity reservoirs are technically challenging [11-16]. This study focuses on the low resistivity thick sandstone in the $\mathrm{X} \sim \mathrm{XII}$ groups of the $\mathrm{K}_{2} q n^{3}$ (the third member of Qingshankou Formation) at Daqingzijing oilfield and summarizes petrophysical well$\log$ response characteristics and its logfacies of low resistivity 


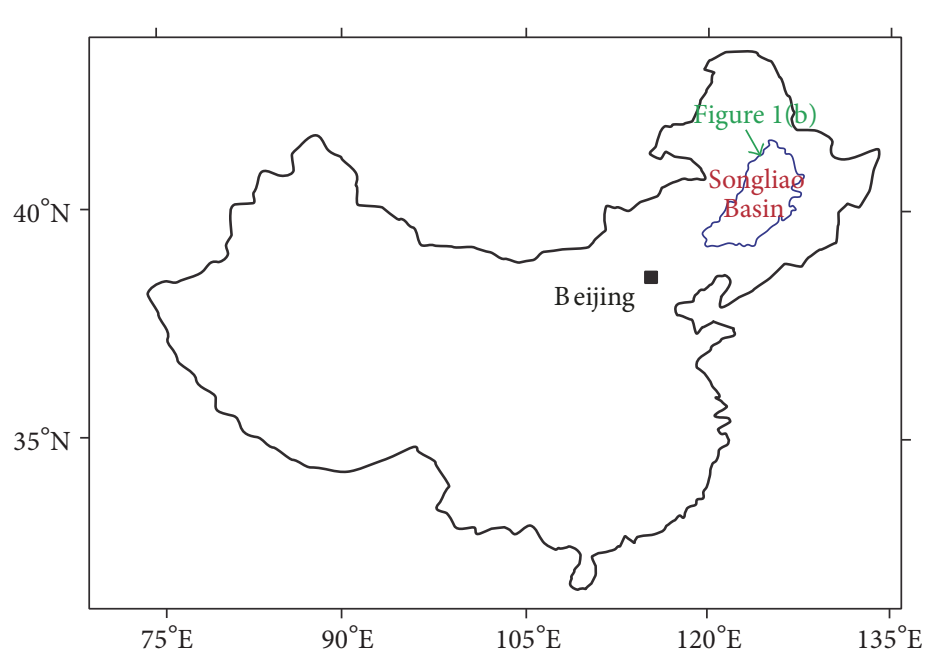

(a)

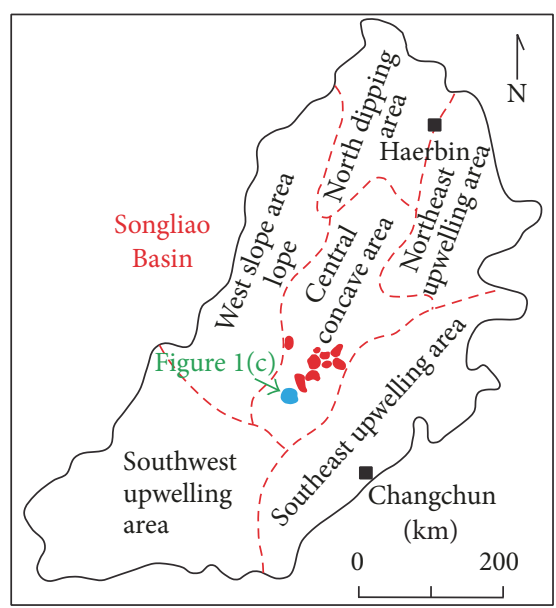

(b)
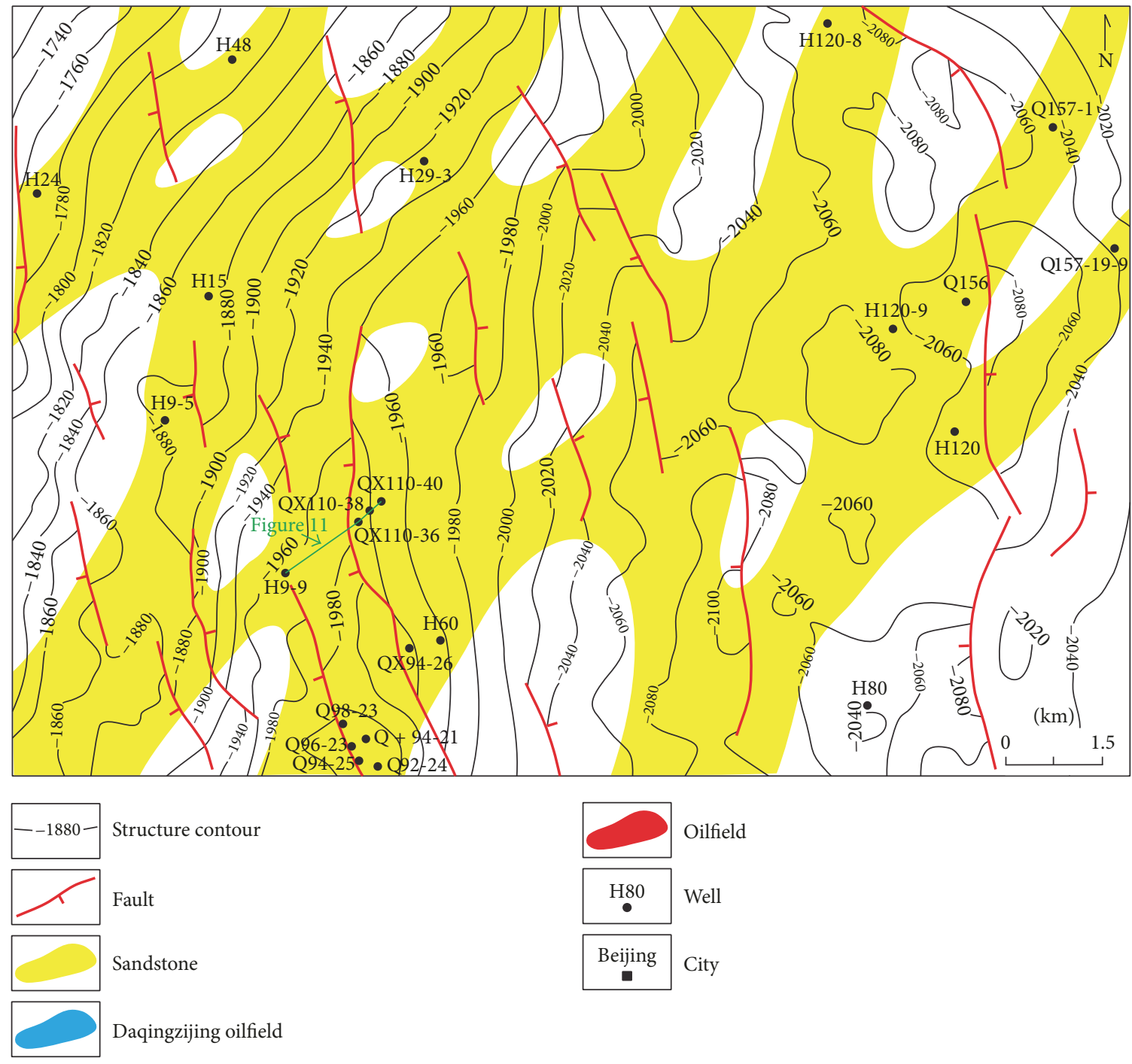

Structure contour

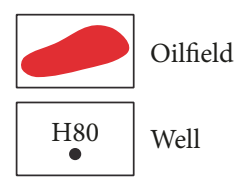

Sandstone

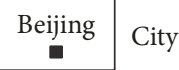

Daqingzijing oilfield

(c)

Figure 1: Location map of the study area. (a) Location map of Songliao Basin. (b) Songliao Basin structural zones. (c) Structural characteristics and sandstone distribution map within the study area. 
thick layer sandstone based on comprehensive well-log, core, oil, and production test data. The petrophysical interpretations of the different types of logging curve are discussed. A secondary aim of this paper is to establish quantitative parameters for identification of the calcareous sandstone, low resistivity reservoir, and reservoir thickness and further understand the causes of low resistivity reservoir in the area. The results will provide guidance for the identification of the calcareous sandstone and low resistivity oil reservoirs elsewhere.

\section{Geological Setting}

2.1. Stratigraphic Characteristics. From bottom to top, the formations of Songliao Basin are the Huoshiling Formation $\left(\mathrm{J}_{3} h\right)$, Shahezi Formation $\left(\mathrm{K}_{1} h\right)$, Yingcheng Formation $\left(\mathrm{K}_{1} y\right)$, Denglouku Formation $\left(\mathrm{K}_{1} d\right)$, Quantou Formation $\left(\mathrm{K}_{1} q\right)$, Qingshankou Formation $\left(\mathrm{K}_{2} q n\right)$, Yaojia Formation $\left(\mathrm{K}_{2} y\right)$, Nenjiang Formation $\left(\mathrm{K}_{2} n\right)$, Sifangtai Formation $\left(\mathrm{K}_{2} s\right)$, Mingshui Formation $\left(\mathrm{K}_{2} m\right)$, Yian Formation $\left(\mathrm{E}_{2} y\right)$, Da'an Formation $(\mathrm{N} d)$, and Taikang Formation $(\mathrm{Q} t)$ [17-19]. The Daqingzijing oilfield has four oil-bearing horizons: the Fuyu, Gaotaizi, Putaohua, and Heidimiao Formations. The main oil-bearing level is Gaotaizi reservoir of the Qingshankou Formation $\left(\mathrm{K}_{2} q n\right)$ (Figure 2(a)) [20]. There are three members that comprise the Qingshankou Formation: these are referred to as $\mathrm{K}_{2} q n^{1}, \mathrm{~K}_{2} q n^{2}$, and $\mathrm{K}_{2} q n^{3}$. Regarded as a deeply buried lacustrine unit, the lithology of $\mathrm{K}_{2} q n^{1}$ is dominated by graydark shale, gray mudstone, argillaceous siltstone, and siltstone; it includes four sand-dominated levels, which range in thickness between 70 and 100 meters. The lithology of $\mathrm{K}_{2} q n^{2}$ is mainly dominated by gray mudstone, argillaceous siltstone, and siltstone representing delta front sedimentary environment; it includes five sand-dominated levels, which range in thickness between 160 and 200 meters. The lithology of $K_{2} q n^{2}$ is mainly dominated by gray mudstone, argillaceous siltstone, siltstone, and sandstone representing distal lacustrine and delta front sedimentary environments (Figure 2(b)) [21].

2.2. Lithology and Physical Property. Based on the identification and analysis of thin sections, lithologies of the X XII sandstones of $\mathrm{K}_{2} q n^{3}$ Formation are identified as lithic arkose and feldspathic lithic sandstone, of which the average content of quartz is $38.5 \%$, feldspar is $51.6 \%$, and lithic fragments are $36.9 \%$ (Figure $3(\mathrm{a})$ ). Core logging shows that the X XII sand groups of $\mathrm{K}_{2} q n^{3}$ Formation consist of calcareous siltstone, calcisiltite, argillaceous siltstone, and siltstone (Figure 3(b)).

Statistical analysis of 336-core sample from 8 cores in the area shows that the porosity of the sandstone of the X XII sand groups of $\mathrm{K}_{2} q n^{3}$ Formation ranges within $8 \% \sim 17 \%$ with an arithmetic mean of $11.7 \%$ (Figure $3(\mathrm{c})$ ). The permeability is distributed within $0.02 \sim 160 \times 10^{-3} \mu \mathrm{m}^{2}$ with average value of $4.5 \times 10^{-3} \mu \mathrm{m}^{2}$ (Figure $3(\mathrm{~d})$ ), all of which indicates that $\mathrm{K}_{2} q n^{3}$ is a typical low porosity and low permeability reservoir.

\section{Well Logging Response Characteristics of Thick Layer Sand Bodies}

3.1. Well Logging Curve Types of Thick Layer Sand Bodies. Distributary channel sand bodies have been interpreted to reside in the delta front sedimentary environment of the study area [7] (Figure 2). Channels are locally amalgamated into sandstone bodies that are $>15 \mathrm{~m}$ thick. The GR curves of the thick sandstones are box type with abrupt changes at top and bottom (Figure 4). In this area a reasonable cut-off for sandstone versus mudstone is 90API.

The RILD (deep induction logging resistivity) and RILM (medium induction logging resistivity) curves of the thick sand bodies are mainly manifested as one of the following 3 profiles. (1) Low amplitude logfacies proffer a low amplitude, nearly flat curve, indicating that the resistivity of the sandstone is similar to the resistivity of overlaying mudstone section (Figure $4(\mathrm{a})$ ), with the average value of RILD between 4.4 and $10 \Omega \cdot \mathrm{m}$ (Table 1). (2) Middle amplitude logfacies near the middle of the logarithmic induction scale again produce a flat curve, indicating that the resistivity of the thick sand bodies is higher than the resistivity of overlaying mudstone section and the low amplitude sandstone (Figures 4 (b) and 4(c)), with the average value of RILD between 7.5 and 13.7 $\Omega \cdot \mathrm{m}$ (Table 1). (3) Sharp-high amplitude logfacies refer to the resistivity of the thick sand bodies that is apparently sharp higher than the resistivity of low and middle amplitude kind (Figures 4(a) and 4(b)), with the average value of RILD between 7.4 and $23.9 \Omega \cdot \mathrm{m}$ (Table 1 ). The sharp-high amplitude induction response is mainly positioned at the top or bottom of thick sandstones (Figures 4(b) and 4(c)). The above 3 kinds of curves of the thick layer sand bodies can be merged together, which are presented as follows: (1) sharp-high, low, and sharp-high amplitude combination (Figure 4(a)); (2) middle, sharp-high amplitude combination (Figure 4(b)); (3) sharp-high, middle, low, and sharp-high amplitude combination (Figure 4(c)); (4) sharp-high, middle, and low amplitude combination (Figure 4(d)).

3.2. Electrical Characteristics of Thick Layer Sand Bodies. Resistivity of thick layer sand bodies of eleven oil test and production wells is shown in Figure 5. The results showed that the RILD and RILM curves present the characteristics of double peak feature. The first peak of RILD is $12 \Omega \cdot \mathrm{m}$; the second peak of RILD is $28 \Omega \cdot \mathrm{m}$ (Figure $5(\mathrm{a})$ ). The first peak of RILM is $10 \Omega \cdot \mathrm{m}$; the second peak of RILM is $28 \Omega \cdot \mathrm{m}$ (Figure 5(b)). Overall, the resistivity of the thick sand bodies is low; as such we characterize it as low resistivity reservoir. Identification of quantitative relationship between the double peaks feature of the three types of logfacies and the variable well-log response makes interpretation of the reservoir fluid content problematic.

\section{Identification of Low Resistivity Oil Layers}

4.1. Identification of Calcareous Interlayers. The RILD and RILM curves are characterized by sharp-high amplitude at the top and bottom of the thick layer sand bodies (Figure 4). There are two likely explanations of the increase of reservoir resistivity: (1) there is oil or natural gas in the sandstone or other nonconducting fluid or gas $[22,23]$; (2) the reservoir is relatively tight (tight reservoir), therefore leading to the increase of resistivity and decrease of acoustic time simultaneously [24]. The AC value of the sharp-high amplitude of 


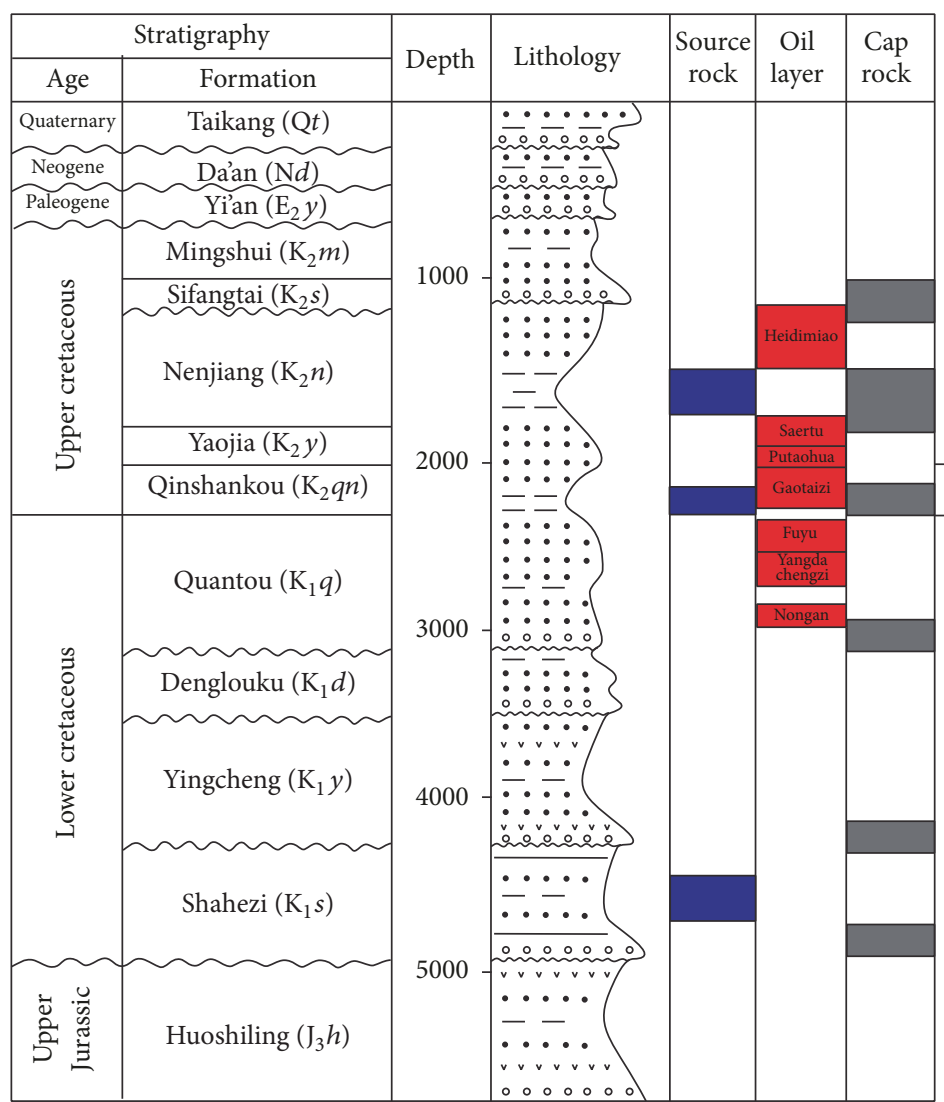

\begin{tabular}{|c|c|}
\hline 二 二 & Mudstone \\
\hline $\begin{array}{ll}\because & \ddot{ }\end{array}$ & Siltstone \\
\hline$=\ddot{n}$ & Argillaceous siltstone \\
\hline$\therefore:$ & Sandstone \\
\hline$\because \because v$ & Volcanic rock \\
\hline
\end{tabular}

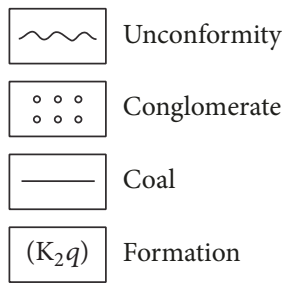

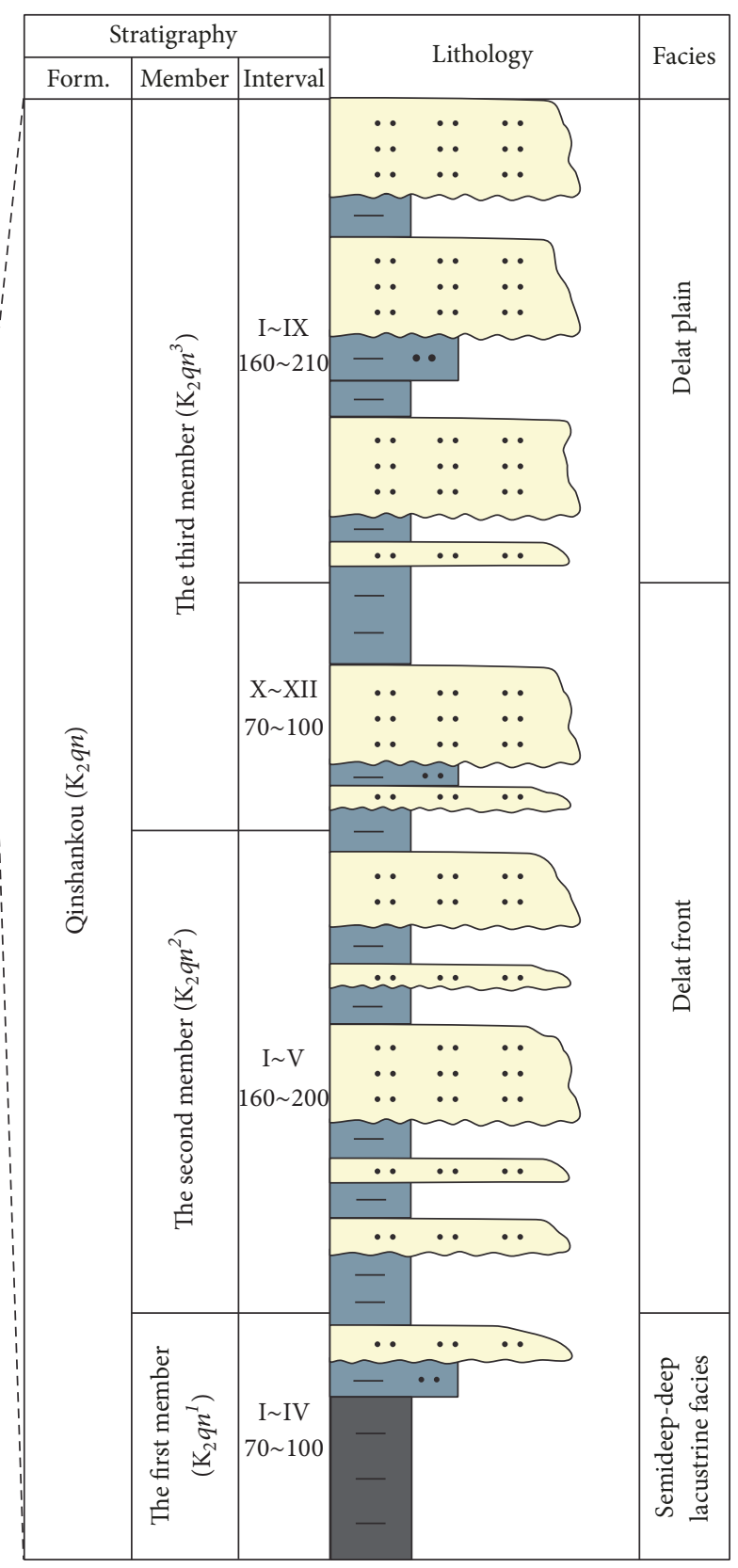

(b)

(a)

FIGURE 2: Stratigraphic column in Daqingzijing area. (a) Stratigraphy of the Songliao Basin. (b) Detailed stratigraphic characteristics of the Qingshankou Formation in the Daqingzijing area of the Songliao Basin.

thick layer sand bodies decreases compared to the middle and low amplitude section (Figure 4 and Table 1). Therefore, the section of sharp-high amplitude (resistivity increases and the acoustic time decreases) likely indicates a tight sandstone section.

Based on the identification of the core samples through the scanning electron microscope, calcite cements are common in the study area (Figure 6). The carbonate content of thick sand bodies in five cored wells ranges from $0.8 \%$ to $58.3 \%$, with the average value of $13.1 \%$; the carbonate cement content of most samples is distributed within $0.8 \% \sim 20 \%$
(Figure $7(\mathrm{a})$ ). Normally, the impact of calcite cements on the porosity of sandstone is relatively small when calcite < $25 \%$. However, above $25 \%$, carbonate crystals fill the void space and pore throats with poikilitic cement. The porosity of sandstone reservoir decreases with increasing carbonate content (Figure 7(b)), leading to increased resistivity and decreased acoustic time. In short, carbonate cementation is the main factor that leads to sharp-high amplitude at the top and bottom of the thick sand bodies in the study area.

As the increase of the resistivity value is mainly caused by carbonate cementation rather than oil or gas in sandstone 


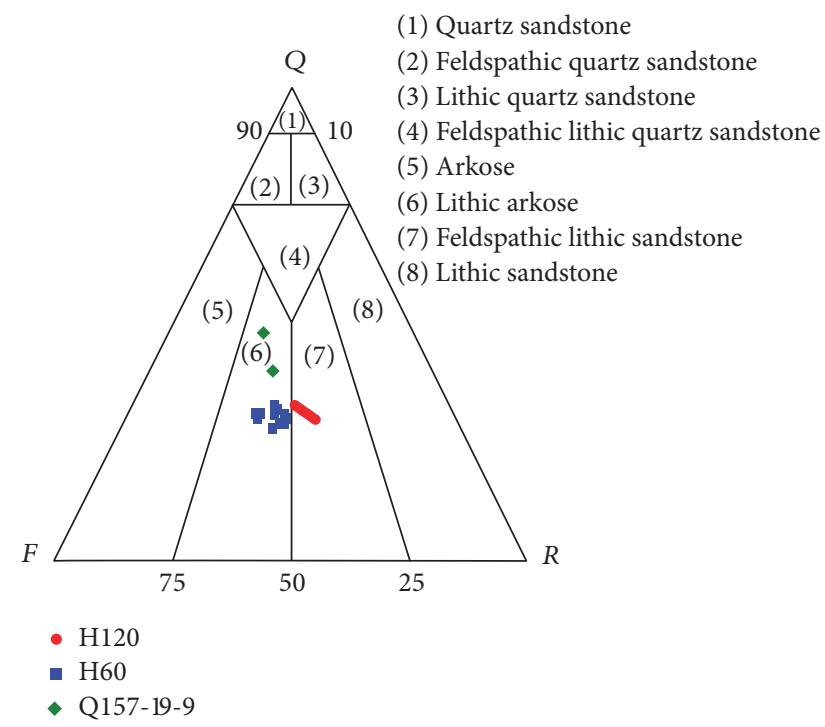

(a)

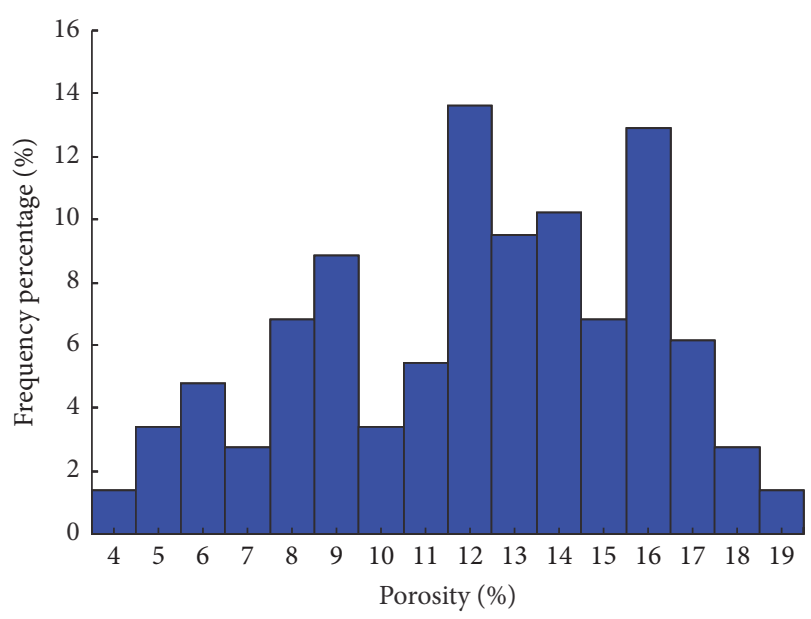

(c)

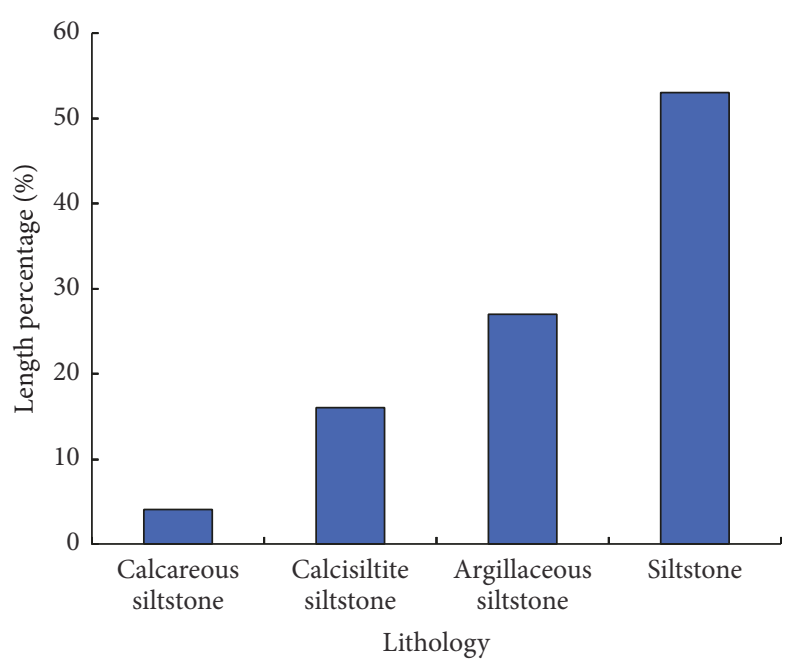

(b)

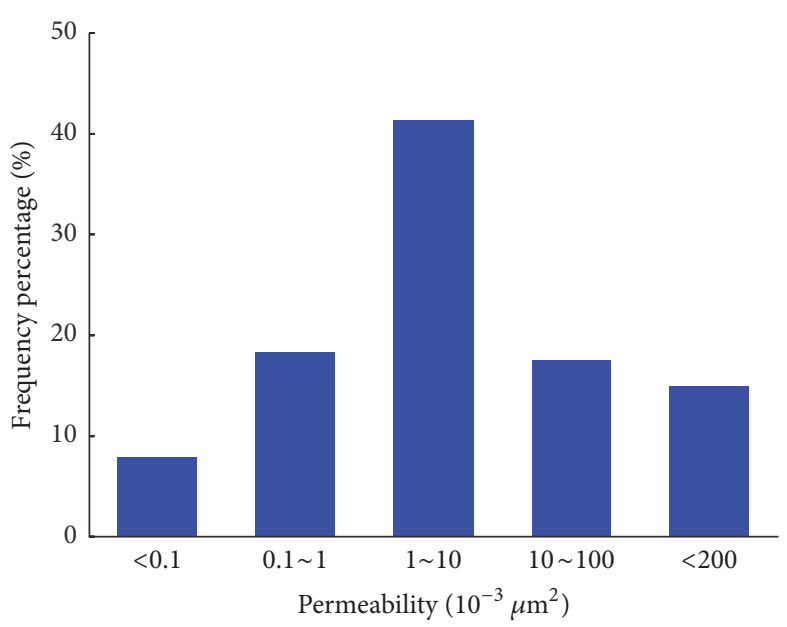

(d)

Figure 3: Diagram of lithology and physical property of the core well at Daqingzijing area. (a) Rock type. (b) Lithologic distribution histogram. (c) Porosity distribution histogram. (d) Permeability distribution histogram.

reservoirs, the sharp-high amplitude of calcareous sandstone section should be identified separately during the process of identifying the oil layer and the water layer based on the resistivity value. Based on the statistics of RILD of sharphigh, middle, and low amplitude of thick layer sand bodies from ten oil tests and production wells, the average RILD of sharp-high amplitude ranges within $7.4 \Omega \cdot \mathrm{m} \sim 26.4 \Omega \cdot \mathrm{m}$ with maximum distributed within $9.1 \Omega \cdot \mathrm{m} \sim 30.3 \Omega \cdot \mathrm{m}$. The average RILD of middle amplitude ranges within $7.5 \Omega \cdot \mathrm{m} \sim 14.1 \Omega \cdot \mathrm{m}$, while the average RILD of low amplitude ranges within $4.4 \Omega \cdot \mathrm{m} \sim 10 \Omega \cdot \mathrm{m}$ (Table 1 ). As shown in the cross plot of RILD and AC of the three above types, there is a significant RILD overlap within $7 \Omega \cdot \mathrm{m} \sim 15 \Omega \cdot \mathrm{m}$ for the sharp-high and middle amplitude, as well as AC overlap within $230 \mu \mathrm{s} / \mathrm{m} \sim 245 \mu \mathrm{s} / \mathrm{m}$ (Figure 8(a)); therefore, it is not practical to identify the calcareous interlayers by using RILD and AC cross plot.

Because the sharp-high, middle, and low amplitude curve types are all based on the comparison of the RILD to that of the adjacent sandstone section, two new parameters, JRT and JAC, were constructed to characterize the relative variability. The specific formula is as follows:

$$
\begin{aligned}
& J R T=\frac{\text { RILD }_{\text {max }}}{\text { RILD }_{\text {ave }}} \\
& J A C=\frac{\mathrm{AC}_{\text {min }}}{\mathrm{AC}_{\text {ave }}} .
\end{aligned}
$$

JRT is relative resistivity, dimensionless; RILD $_{\max }$ is maximum RILD of sandstone section in the adjacent sharp-high amplitude, $\Omega \cdot \mathrm{m} ; \mathrm{RILD}_{\text {ave }}$ is average RILD of sandstone section in the sharp-high, middle, and low amplitude, $\Omega \cdot \mathrm{m}$; JAC is relative acoustic, dimensionless; $\mathrm{AC}_{\min }$ is minimum $\mathrm{AC}$ of sandstone section in the adjacent sharp-high amplitude, $\mu \mathrm{s} / \mathrm{m} ; \mathrm{AC}_{\text {ave }}$ is average $\mathrm{AC}$ of sandstone section in the sharphigh, middle, and low amplitude, $\mu \mathrm{s} / \mathrm{m}$; JRT and JAC were calculated according to (1) for sharp-high, middle, and low 

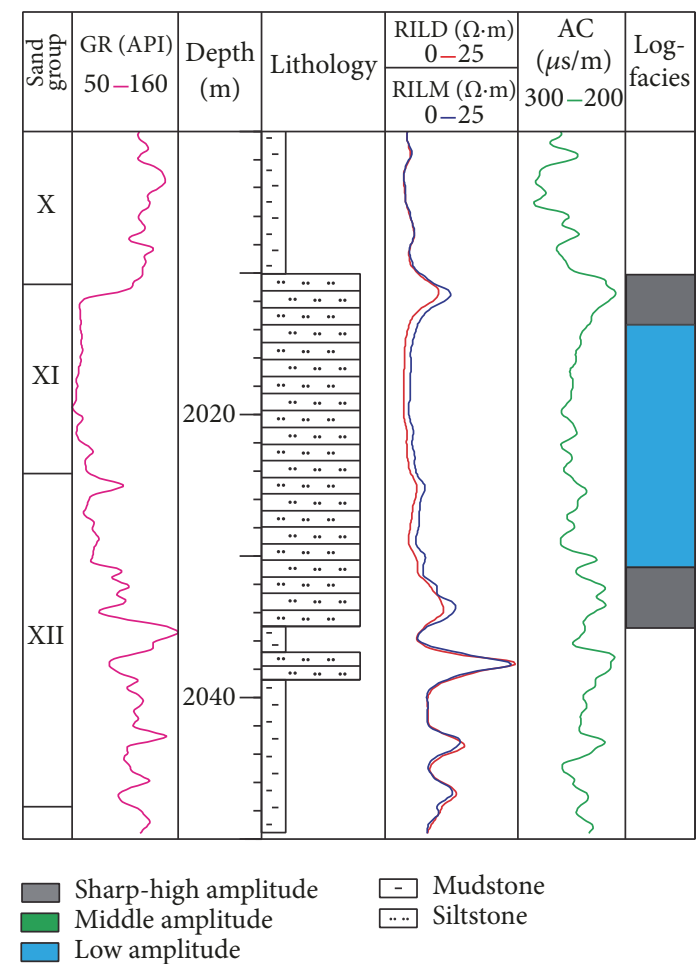

(a)

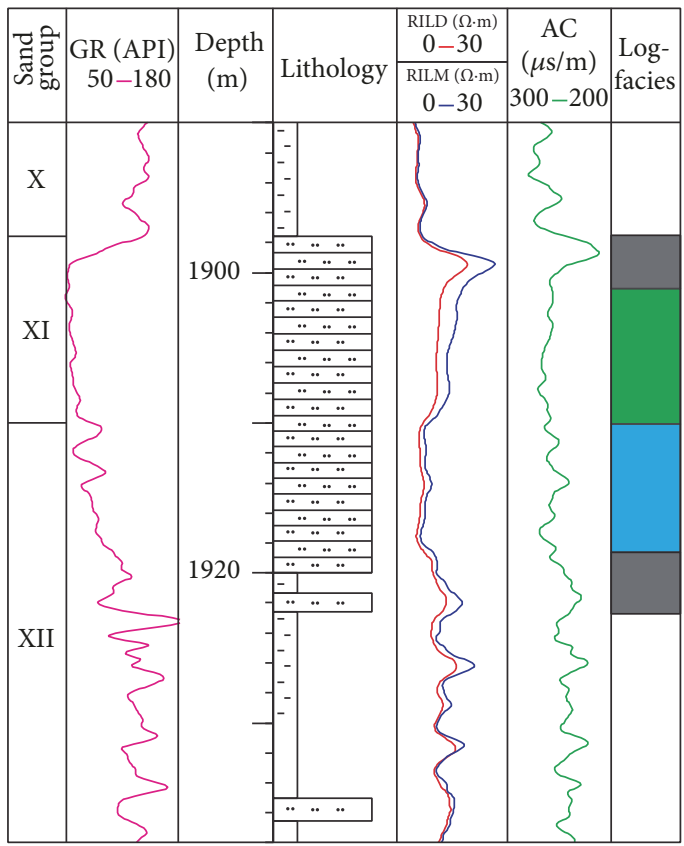

Sharp-high amplitude Middle amplitude Low amplitude

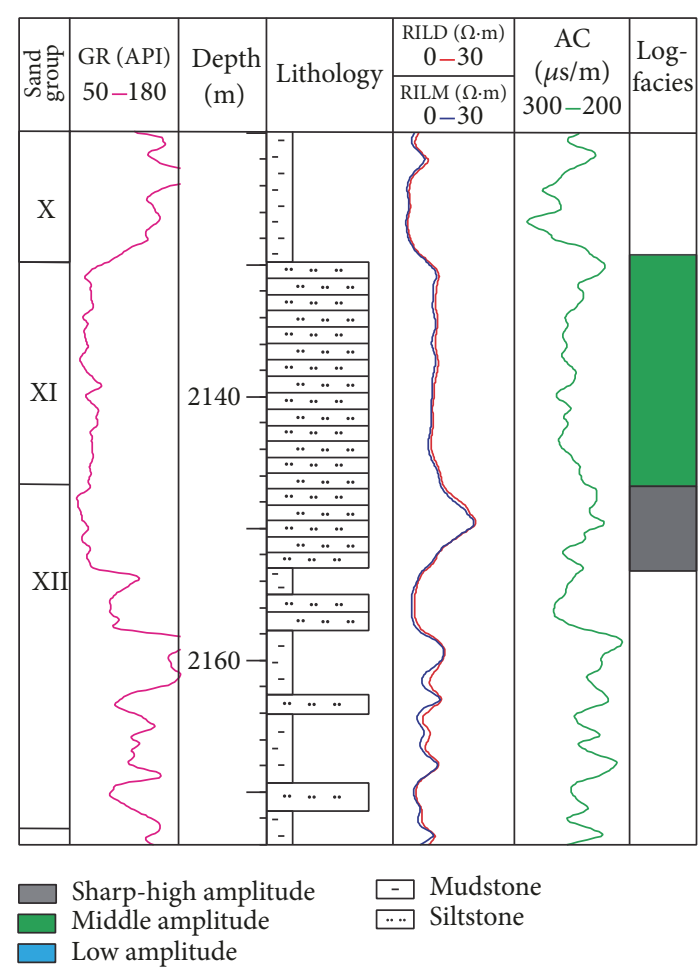

(b)

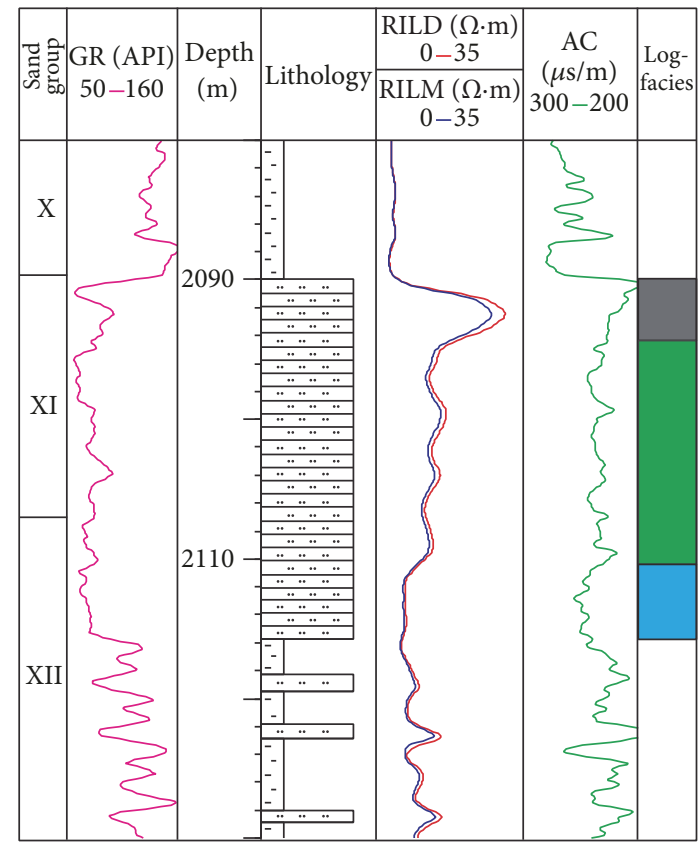

Sharp-high amplitude Middle amplitude Low amplitude

(c)

\section{$\begin{array}{ll}- & \text { Mudstone } \\ -\cdots & \text { Siltstone }\end{array}$}

\section{- Mudstone Siltstone}

(d)

FIGURE 4: Petrophysical log response characteristics and logfacies of thick sand bodies in the Daqingzijing. (a) Integrated petrophysical and geological dataset of H15 well. (b) Integrated petrophysical and geological dataset of Qx 94-26 well. (c) Integrated petrophysical and geological dataset of H24 well. (d) Integrated petrophysical and geological dataset of Qx 110-36 well. GR means natural gamma ray logging, RILD means deep induction logging resistivity, RILM means medium induction logging resistivity, and AC means acoustic logging. 
TABLE 1: Response value of different curve types of thick layer sand bodies.

\begin{tabular}{|c|c|c|c|c|c|c|c|c|c|}
\hline \multirow{3}{*}{$\begin{array}{l}\text { Well } \\
\text { H120-8 }\end{array}$} & \multicolumn{2}{|c|}{$\begin{array}{l}\text { Interval depth } \\
\text { (m) }\end{array}$} & \multirow{2}{*}{$\begin{array}{l}\text { Logfacies } \\
\text { Sharp-high }\end{array}$} & \multirow{2}{*}{$\begin{array}{c}\text { RILD }_{\text {ave }} \\
(\Omega \cdot \mathrm{m})\end{array}$} & \multirow{2}{*}{$\begin{array}{c}\mathrm{RILD}_{\max } \\
(\Omega \cdot \mathrm{m}) \\
13.2\end{array}$} & \multirow{2}{*}{$\begin{array}{c}\text { JRT } \\
1.2\end{array}$} & \multirow{2}{*}{$\begin{array}{c}\begin{array}{c}\mathrm{AC}_{\mathrm{ave}} \\
(\mu \mathrm{s} / \mathrm{m})\end{array} \\
219.2\end{array}$} & \multirow{2}{*}{$\begin{array}{c}\mathrm{AC}_{\min } \\
(\mu \mathrm{s} / \mathrm{m})\end{array}$} & \multirow{2}{*}{$\begin{array}{l}\text { JAC } \\
0.98\end{array}$} \\
\hline & 2188 & 2192 & & & & & & & \\
\hline & 2192 & 2212 & Middle & 8.4 & & 1.6 & 242.7 & & 0.89 \\
\hline \multirow{4}{*}{$\mathrm{H} 24$} & 1898 & 1901 & Sharp-high & 9.4 & 12.8 & 1.4 & 235.2 & 210.7 & 0.90 \\
\hline & 1901 & 1910 & Middle & 7.5 & & 1.7 & 261.4 & & 0.81 \\
\hline & 1910 & 1918 & Low & 4.4 & & 2.1 & 256.4 & & 0.82 \\
\hline & 1918 & 1922 & Sharp-high & 7.4 & 9.1 & 1.2 & 241.2 & 228.6 & 0.95 \\
\hline \multirow{3}{*}{ H15 } & 2010 & 2013 & Sharp-high & 7.4 & 10 & 1.4 & 223.1 & 209.7 & 0.94 \\
\hline & 2013 & 2031 & Low & 4.4 & & 2.3 & 250.4 & & 0.84 \\
\hline & 2031 & 2035 & Sharp-high & 8.9 & 11 & 1.2 & 231.9 & 218.7 & 0.94 \\
\hline \multirow{2}{*}{ H120-9 } & 2215 & 2229 & Middle & 10 & & 1.4 & 238.2 & & 0.87 \\
\hline & 2229 & 2235 & Sharp-high & 11.8 & 14.2 & 1.2 & 215.1 & 208.3 & 0.97 \\
\hline \multirow{2}{*}{ Qx94-26 } & 2130 & 2147 & Middle & 10.4 & & 2.0 & 252.2 & & 0.88 \\
\hline & 2147 & 2153 & Sharp-high & 14.9 & 20.4 & 1.4 & 237.4 & 222 & 0.94 \\
\hline \multirow{3}{*}{ Q98-23 } & 2130 & 2138 & Sharp-high & 18.5 & 22 & 1.2 & 220.7 & 211.1 & 0.96 \\
\hline & 2138 & 2147 & Middle & 14.1 & & 1.6 & 238.5 & & 0.89 \\
\hline & 2147 & 2152 & Low & 10 & & 2.2 & 242.6 & & 0.87 \\
\hline \multirow{2}{*}{$\mathrm{Q}+94-21$} & 2130 & 2156 & Middle & 10.7 & & 2.8 & 231.9 & & 0.86 \\
\hline & 2156 & 2162 & Sharp high & 26.4 & 30.1 & 1.1 & 224.4 & 198.8 & 0.89 \\
\hline \multirow{2}{*}{ Q94-25 } & 2122 & 2139 & Middle & 10.7 & & 2.8 & 233.4 & & 0.88 \\
\hline & 2139 & 2146 & Sharp-high & 22.9 & 30.3 & 1.3 & 216 & 206.5 & 0.96 \\
\hline \multirow{2}{*}{ Q96-23 } & 2130 & 2157 & Middle & 12.6 & & 2.3 & 244.7 & & 0.88 \\
\hline & 2157 & 2162 & Sharp-high & 22 & 28.9 & 1.3 & 228.4 & 215.9 & 0.95 \\
\hline \multirow{3}{*}{ Qx110-36 } & 2090 & 2094 & Sharp-high & 23.9 & 27.7 & 1.2 & 217.2 & 193.6 & 0.89 \\
\hline & 2094 & 2110 & Middle & 13.7 & & 2.0 & 234.3 & & 0.83 \\
\hline & 2110 & 2115 & Low & 7.2 & & 3.8 & 247.4 & & 0.78 \\
\hline
\end{tabular}

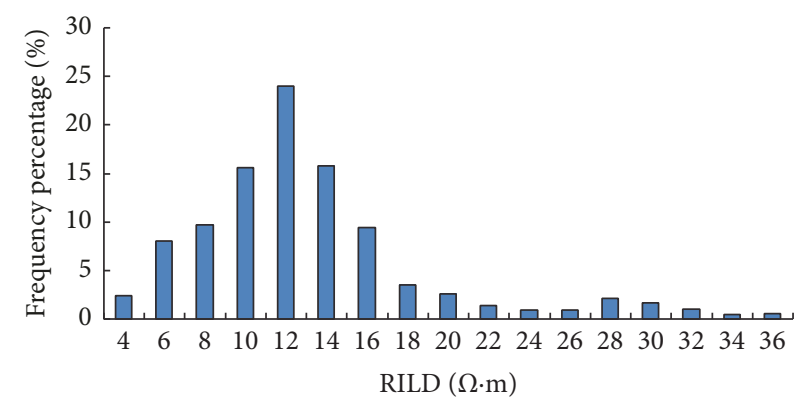

(a)

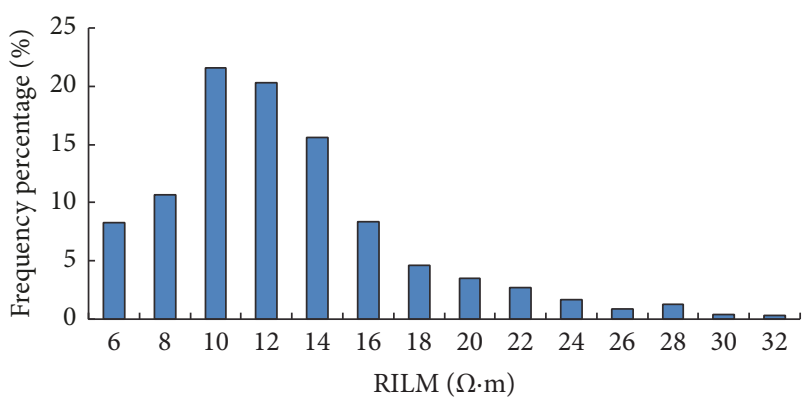

(b)

FIGURE 5: Histogram of the resistivity of the thick layer sand bodies in Daqingzijing. (a) RILD resistivity distribution histogram. (b) RILM resistivity distribution histogram.

amplitude of sandstone section (Table 1). As indicated from the JRT and JAC cross plot, JRT value of the sharp-high amplitude sandstone is less than 1.4 , and the JAC value is greater than 0.88 , while the JRT value of middle and low amplitude sandstone is greater than 1.4, and the JAC value is less than 0.88 (Figure 8(b)). The cross plot of JRT and JAC can clearly distinguish the sharp-high, middle, and low amplitude sandstone and identify the sharp-high amplitude calcareous sandstone.
4.2. Identification of Low Resistivity Oil Layers. Based on the statistics of the RILD of middle and low amplitude of thick sandstone in ten oil test and production well, the average RILD in the middle amplitude sandstone section is between $7.5 \Omega \cdot \mathrm{m}$ and $14.1 \Omega \cdot \mathrm{m}$, while in the low amplitude sandstone section it is between $4.4 \Omega \cdot \mathrm{m}$ and $10 \Omega \cdot \mathrm{m}$ (Table 1 ), leading to a significant overlap for the RILD of middle and low amplitude sandstone in the range of $7.5 \Omega \cdot \mathrm{m} \sim 10 \Omega \cdot \mathrm{m}$; this makes it hard to identify the oil and water layer with only 

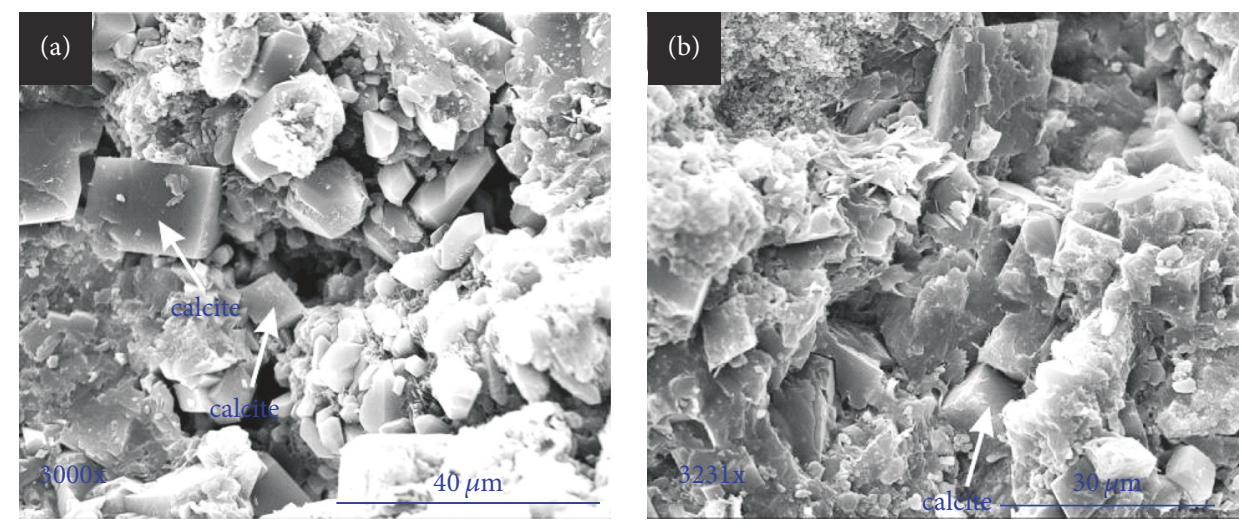

FIGURE 6: Scanning electron microscope of sandstone samples from the thick sand bodies in the Daqingzijing area. (a) Calcite cementation in H47 well $2171.1 \mathrm{~m}$. (b) Calcite cement in Q156 well $2191.8 \mathrm{~m}$.

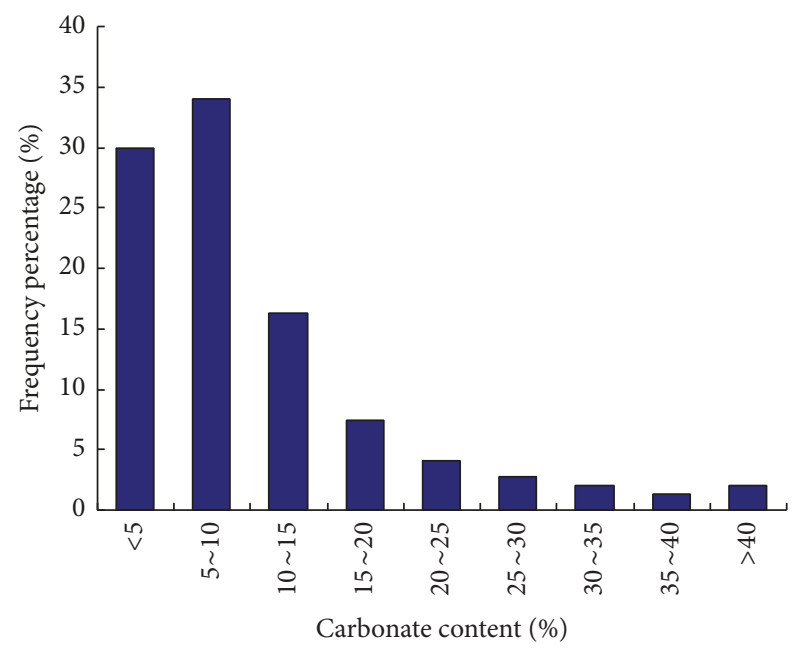

(a)

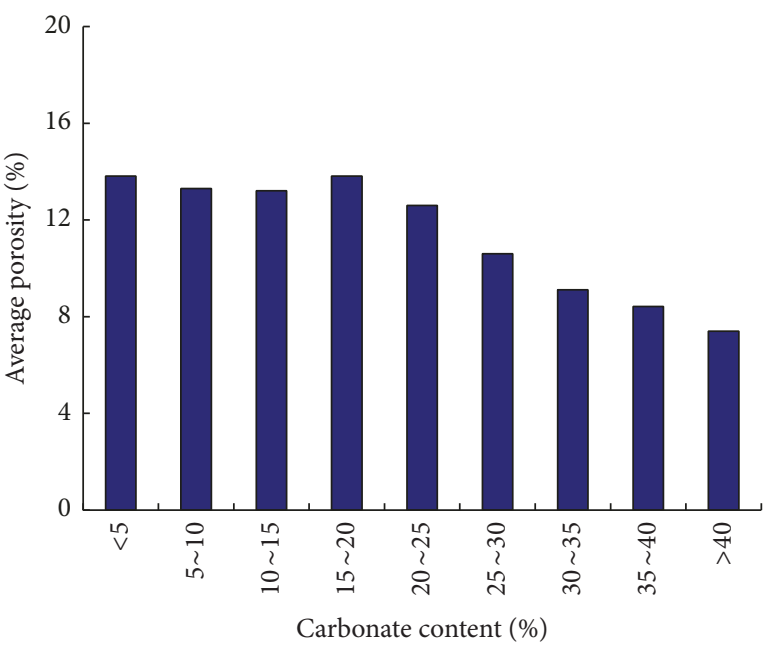

(b)

FIGURE 7: The distribution of carbonate content and its relationship with average porosity. (a) Carbonate content distribution histogram. (b) Carbonate content and average porosity.

RILD. For example, in the H24 well, the average RILD in the middle amplitude sandstone section is $8.2 \Omega \cdot \mathrm{m}$, and the test data proves it as water layer, while in the Qx110-36 well, the average RILD in the middle amplitude sandstone section is 13.7 $\Omega \cdot \mathrm{m}$, but the test data proves it as oil-water layer (Table 2 ).

The data from eleven test and production wells in the study area show that the average RILM is greater than the average RILD in water layer sandstone (Table 2), such as in H15 (Figure 4(a)) and H24 (Figure 4(c)). The average RILD is greater than the average RILM in oil layer sandstone (Table 2), such as in Qx94-26 (Figure 4(b)) and Qx110-36 (Figure 4(d)). This is due to a fact that the formation of water resistivity is less than that of mud filtrate, and the mud filtrate resistivity is less than that of oil layer. When the mud filtrate invades into the water layer, the resistivity of the mixed formation water in the intrusive zone is certainly greater than that of the water layer, which explains why RILM value is greater than RILD. Moreover, if the mud filtrate invades into oil layer, the resistivity of the mixed liquid in the invasion zone is expected to be less than that of the oil layer, and consequently RILD is greater than RILM.

A new parameter $\triangle \mathrm{RT}$ is constructed based on the characteristics of RILD and RILM, which is the average RILD minus the average RILM. Based on the analysis between productivity and cross plot of $\triangle \mathrm{RT}$ and RILD, we can found that the water layer's $\Delta \mathrm{RT}$ is less than 0 , such as H120-8, H24, H15, and H120-9 (Table 2, Figure 9). However, the oilwater layer's $\Delta \mathrm{RT}$ is greater than 0 , such as H160, Qx94-26, Qx92-24, Q98-23, Q+94-21, Q94-25, Q96-23, and Qx110-36 (Table 2, Figure 9).

Based on the statistical results of resistivity of the test and the production data (Table 2), the RILD and RILM cross plot is regarded as a standard resistivity identification method to distinguish oil-water layer from water layer, whereas the average value of RILM is difficult to distinguish the oil-water layer from water layer (Figure 10). The average RILD is greater than $10.4 \Omega \cdot \mathrm{m}$ in oil-water layer and less than $10.4 \Omega \cdot \mathrm{m}$ in water layer (Figure 10, Table 2), because the average RILD of 


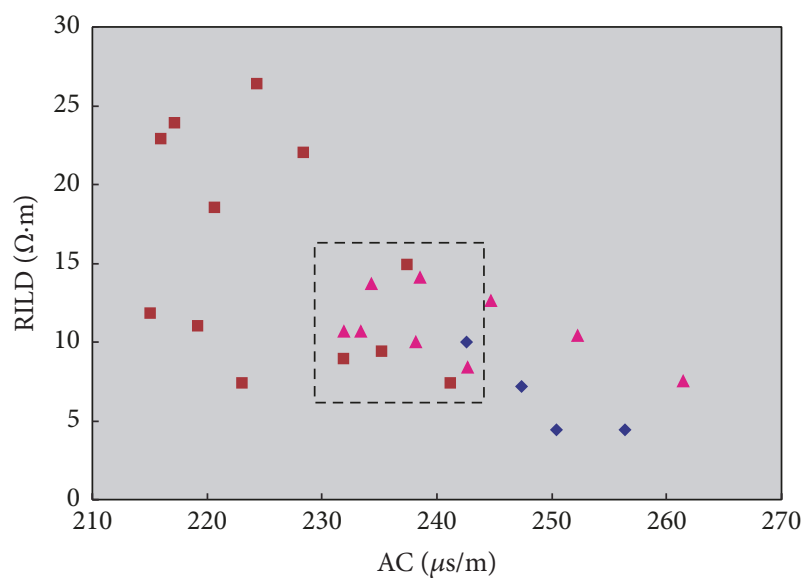

- Low amplitude

^ Middle amplitude

- Sharp-high amplitude

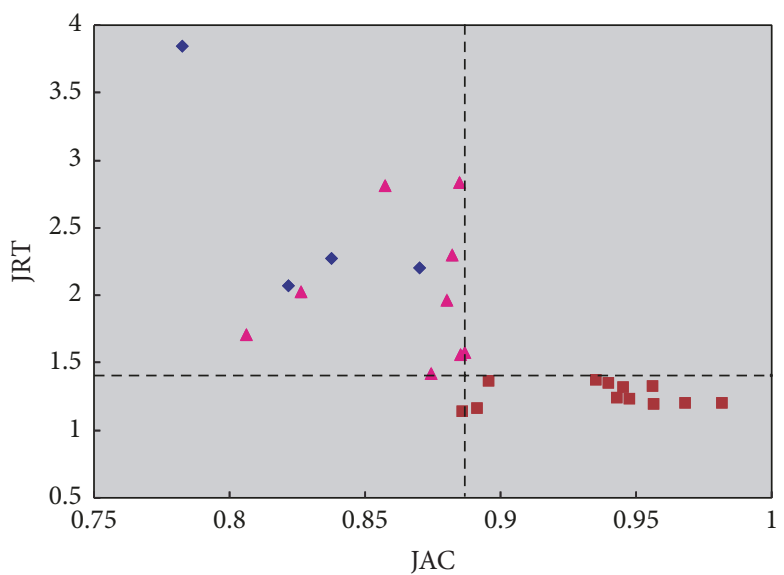

- Low amplitude

- Middle amplitude

- Sharp-high amplitude

(a)

(b)

FIGURE 8: Standard identification of calcareous interlayers (sharp-high amplitude logfacies). (a) Cross plot of the parameters RILD and AC is invalid to identify low amplitude, middle amplitude, and sharp-high amplitude logfacies. (b) Cross plot of the parameters JRT and JAC is effective to identify sharp-high amplitude type from those three logfacies.

TABLE 2: Production distribution of part of wells in the area of the Daqingzijing.

\begin{tabular}{|c|c|c|c|c|c|c|c|c|c|}
\hline \multirow{2}{*}{$\begin{array}{l}\text { Well } \\
\text { H120-8 }\end{array}$} & \multirow{2}{*}{$\begin{array}{c}\text { Logfacies } \\
\text { Middle }\end{array}$} & \multicolumn{2}{|c|}{$\begin{array}{c}\text { Test interval } \\
(\mathrm{m})\end{array}$} & \multirow{2}{*}{$\begin{array}{l}\Delta \mathrm{RT} \\
-4.7\end{array}$} & \multirow{2}{*}{$\begin{array}{c}\text { RILD }_{\text {ave }} \\
(\Omega \cdot \mathrm{m})\end{array}$} & \multirow{2}{*}{$\begin{array}{c}\text { RILM }_{\text {ave }} \\
(\Omega \cdot \mathrm{m}) \\
14.7\end{array}$} & \multirow[t]{2}{*}{$\begin{array}{l}\text { Oil } \\
\text { t/day }\end{array}$} & \multirow{2}{*}{$\begin{array}{c}\text { Water } \\
\text { t/day } \\
7.73\end{array}$} & \multirow{2}{*}{$\begin{array}{c}\text { Test/production } \\
\text { Water layer }\end{array}$} \\
\hline & & 2192 & 2196 & & & & & & \\
\hline $\mathrm{H} 24$ & Middle & 1901 & 1905 & -2.8 & 8.2 & 11 & & 24.6 & Water layer \\
\hline H15 & Sharp-high & 2031 & 2035 & -1.3 & 9.4 & 10.7 & & 55.4 & Water layer \\
\hline H120-9 & Middle & 2220.4 & 2228.4 & -2.1 & 10.2 & 12.3 & & 5.6 & Water layer \\
\hline Qx94-26 & Middle & 2130 & 2147 & 0.7 & 10.4 & 9.7 & 8.3 & 21.2 & Oil-water layer \\
\hline Qx92-24 & Middle & 2134 & 2158 & 1 & 13 & 12 & 7.4 & 15.5 & Oil-water layer \\
\hline Q98-23 & Middle & 2138 & 2147 & 1.4 & 15.6 & 14.2 & 5.4 & 9.2 & Oil-water layer \\
\hline $\mathrm{Q}+94-21$ & Middle & 2130 & 2156 & 0.9 & 11.1 & 10.2 & 2.2 & 5.2 & Oil-water layer \\
\hline Q94-25 & Middle & 2125 & 2135 & 1.7 & 10.7 & 9 & 11 & 15.4 & Oil-water layer \\
\hline Q96-23 & Middle & 2130 & 2140 & 1.7 & 13.4 & 11.7 & 10 & 13.4 & Oil-water layer \\
\hline Qx110-36 & Middle & 2094 & 2110 & 1 & 13.7 & 12.7 & 8.9 & 23.6 & Oil-water layer \\
\hline
\end{tabular}

low amplitude sandstone is less than $10 \Omega \cdot \mathrm{m}$ (Table 2 ), so low amplitude type sandstones are all water layer; if the average RILD of middle amplitude sandstone is greater than $10.4 \Omega \cdot \mathrm{m}$, it is oil-water layer, or else, it is water layer (Table 1).

Based on the deduction of the sharp-high amplitude calcareous interlayers, the fluid identification standard of thick layer sand bodies is as follows: (1) if the sandstone is low amplitude type and $\Delta$ RT (RILD-RILM) $<0$, it is water layer; (2) if the sandstone is middle amplitude type, the average RILD $<10.4 \Omega \cdot \mathrm{m}$, and $\Delta \mathrm{RT}($ RILD-RILM) $<0$, it is water layer; (3) if the sandstone is middle amplitude type, the average RILD $>10.4 \Omega \cdot \mathrm{m}$, and $\Delta \mathrm{RT}($ RILD-RILM) $>0$, it is oilwater layer.

\section{Discussion}

Sandstone in the X XII sand groups of $\mathrm{K}_{2} q n^{3}$ at Daqingzijing oilfield is regarded as a typical low resistivity oil layer. Genetic factors of low resistivity oil layer are very diverse, with low amplitude structure [25], sedimentary facies [26], interstitial materials [27], irreducible water [28], formation water salinity [29], drilling mud invasion, and other factors. This paper will discuss four aspects: low amplitude structure, interstitial material, irreducible water, and formation water salinity.

5.1. Low Amplitude Structure. The sandstone thickness of oil-water layers which is characterized by middle amplitude 


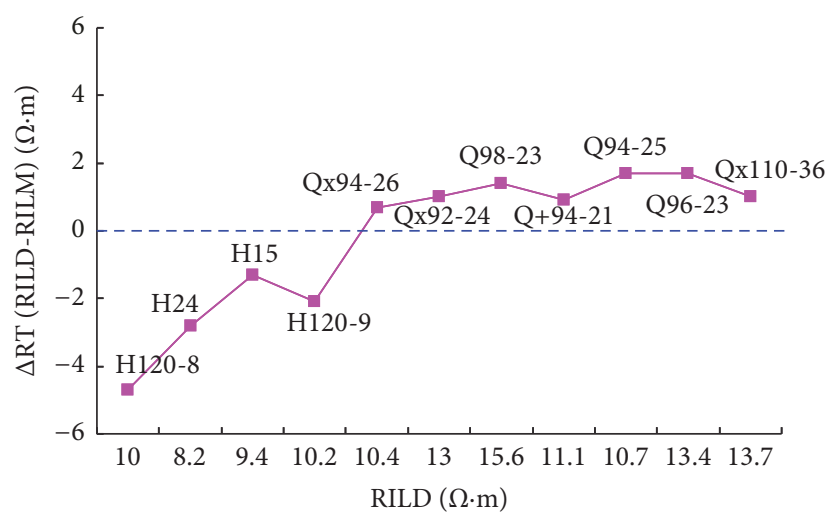

FIGURE 9: $\triangle \mathrm{RT}$ and RILD cross plot of thick layer sand bodies at Daqingzijing area.

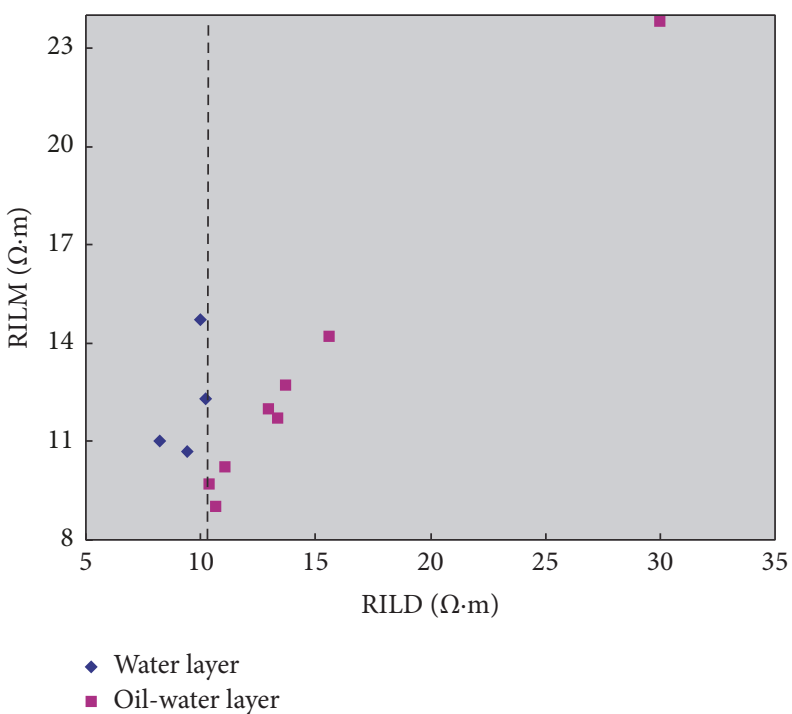

FIGURE 10: RILD and RILM cross plot at Daqingzijing area.

curve type has various values (Table 2); because the reservoir of the study area is low structure reservoir, the oil column height is less than $20 \mathrm{~m}$. Different area of drilling wells in the oil reservoir is considered as oil-water layer if the sand body was on top of the oil-water interface and characterized by middle amplitude curve type; the thickness of the middle amplitude curve segment is the oil layer thickness (Figures 1(c) and 11, Qx110-36). However, it is considered as water layer if the sand body was under the oil-water interface and characterized by low amplitude curve type (Figures 1(c) and 11, Qx110-38, Qx110-40). Moreover, the sharp-high type sandstone because of calcareous interlayer is distributed at the top of the thick layer sand body and is effective cap rock.

5.2. Characteristics of Interstitial Materials. Through a quantitative analysis of $\mathrm{X}$ diffraction data, the total amount of clay minerals of the low resistivity oil layer of $\mathrm{K}_{2} q n^{3}$ varies within $1.8 \% \sim 5.8 \%$, with an average of amounts to $4 \%$. The clay mineral compositions are mainly dominated by illitemontmorillonite mixed-layer and illite, with high cation exchange adsorption capacity and strong conductivity. In addition, most of the cementing materials were subject to argillization due to the epigenesis, which may provide a desirable condition for the existence of a large number of irreducible water [30], therefore forming a good conductive system that reduces reservoir resistivity.

5.3. Characteristics of Formation Irreducible Water. Based on the NMR data in well Q157-19-9, T2 cut-off method showed that the irreducible water saturation is around 30\% 65\%. High irreducible water saturation makes the formation serve as an effective molecular conductive network. This leads to a relatively low resistivity of the oil formation in a fresh water environment (Figure 12).

5.4. Salinity Characteristics of Formation Water. The formation water salinity in the Daqingzijing area of $\mathrm{K}_{2} q n^{3}$ differs largely, ranging from $23662.4 \mathrm{mg} / \mathrm{L}$ to $28317.1 \mathrm{mg} / \mathrm{L}$, with a mean value of $26257.6 \mathrm{mg} / \mathrm{L}$. Statistical results of formation water salinity showed that the regional salinity is relatively high; this indicates that the low resistivity reservoir is related to the high formation water salinity of $\mathrm{K}_{2} q n^{3}$ Formation (Table 3). 


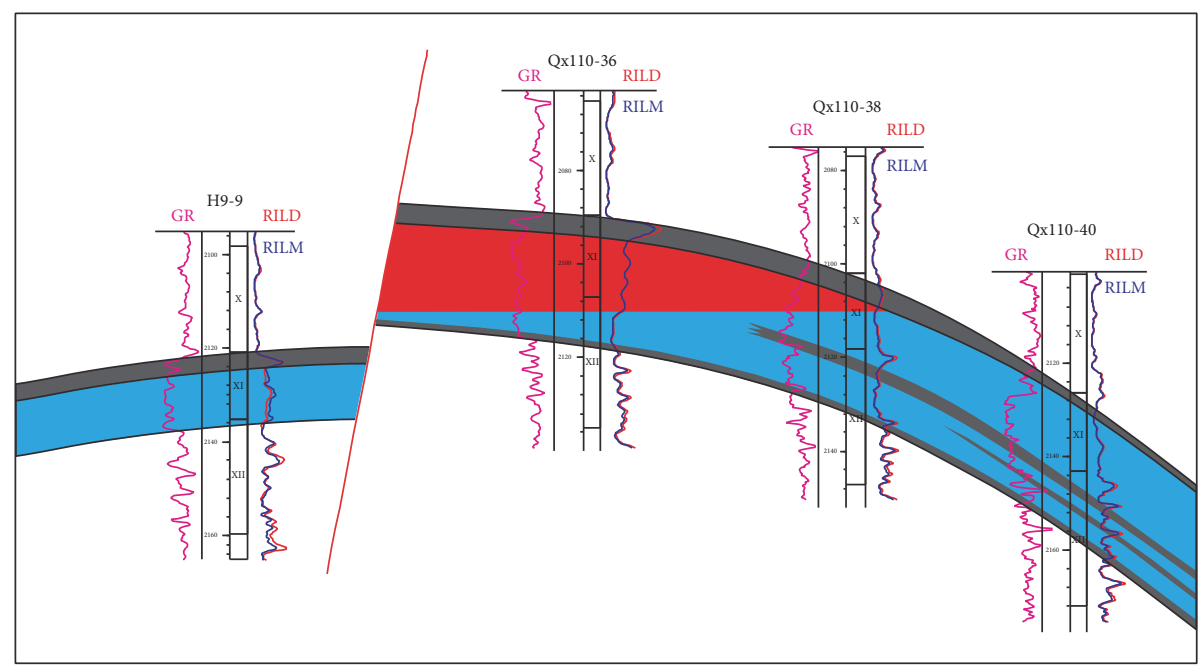

Calcareous sandstone Oil-water layer

Water layer

FIGURE 11: Reservoir profile of H9-9 Qx110-40 at Daqingzijing area. The thickness of the middle amplitude curve segment is the oil layer thickness.

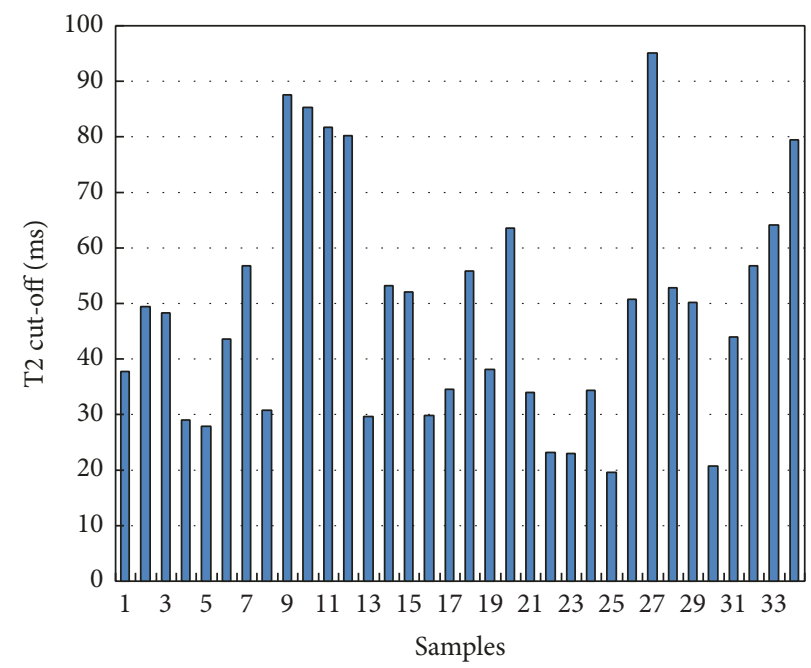

FIGURE 12: T2 cut-off value and irreducible water saturation distribution in the area of Daqingzijing.

TABLE 3: Salinity statistics of Daqingzijing area.

\begin{tabular}{lcccccccc}
\hline Well & $\begin{array}{c}\mathrm{K}^{+}-\mathrm{Na}^{+} \\
(\mathrm{mg} / \mathrm{L})\end{array}$ & $\begin{array}{c}\mathrm{Mg}^{2+} \\
(\mathrm{mg} / \mathrm{L})\end{array}$ & $\begin{array}{c}\mathrm{Ca}^{2+} \\
(\mathrm{mg} / \mathrm{L})\end{array}$ & $\begin{array}{c}\mathrm{Cl}^{-} \\
(\mathrm{mg} / \mathrm{L})\end{array}$ & $\begin{array}{c}\mathrm{SO}_{4}{ }^{2-} \\
(\mathrm{mg} / \mathrm{L})\end{array}$ & $\begin{array}{c}\mathrm{CO}_{3}{ }^{2-} \\
(\mathrm{mg} / \mathrm{L})\end{array}$ & $\begin{array}{c}\text { Total } \\
(\mathrm{mg} / \mathrm{L})\end{array}$ \\
\hline Q157-17-9 & 9820.9 & 23.1 & 178.4 & 10528.6 & 5589.7 & 1501.1 & $\mathrm{NaHCO} 3$ & 27641.8 \\
Q157-1 & 10038.1 & 15.6 & 171.9 & 10324.8 & 6308.3 & 1458.4 & $\mathrm{NaHCO} 3$ & 28317.1 \\
H80 & 9108.9 & 19 & 291.8 & 11229.9 & 3958.6 & 801.2 & $\mathrm{NaHCO} 3$ & 25409.4 \\
H120 & 8420.5 & 67.6 & 227.3 & 10335.1 & 3621.5 & 990.4 & NaHCO3 & 23662.4 \\
\hline
\end{tabular}




\section{Conclusion}

(1) The resistivity of the thick layer sand body of the study area is mainly distributed within $6 \Omega \cdot \mathrm{m} \sim 32 \Omega \cdot \mathrm{m}$ and is featured as double peak; this indicates that the thick layer is a typical low resistivity reservoir. The resistivity curves of the thick layer sand bodies include three logfacies: low, middle, and sharp-high amplitude, and each of them can be merged together, which are presented as the following 4 types: sharphigh, low, sharp-high amplitude combination; middle, sharphigh combination; sharp-high, middle, low, sharp-high amplitude combination; and sharp-high, middle, low amplitude combination.

(2) Thick sandstone of sharp-high amplitude (resistivity increases and the acoustic time decreases) represents the tight sandstone with calcareous cementation. Low amplitude sandstone is water layer while $\Delta \mathrm{RT}$ (RILD-RILM) $<0$. For middle amplitude sandstone, if the average RILD $<10.4 \Omega \cdot \mathrm{m}$ and $\triangle$ RT $($ RILD-RILM) $<0$, it is water layer; while if the average $\mathrm{RILD}>10.4 \Omega \cdot \mathrm{m}$ and $\Delta \mathrm{RT}(\mathrm{RILD}-\mathrm{RILM})>0$, it should be oil-water layer.

(3) The features of low amplitude structure, high clay mineral content, high irreducible water saturation, and high formation water salinity in this study area all make the formation as an effective molecular conductive network. This greatly enhances the conductibility and leads to the low resistivity of the reservoir.

\section{Conflicts of Interest}

The authors declare that they have no conflicts of interest.

\section{Acknowledgments}

This study was supported by National Natural Science Foundation of China (nos. 41502127, 41390451, and 41204094), Opening Foundation of State Key Laboratory of Continental Dynamics, Northwest University (no. BJ14267), and Postdoctoral Fund of China (no. 2015M572594).

\section{References}

[1] J. Ren, K. Tamaki, S. Li, and Z. Junxia, "Late Mesozoic and Cenozoic rifting and its dynamic setting in Eastern China and adjacent areas," Tectonophysics, vol. 344 , no. 3-4, pp. 175-205, 2002.

[2] L. S. Shu, Y. F. Mu, and B. C. Wang, "The oil-gas-bearing strata and the structural features in the Songliao Basin, NE China," Journal of Stratigraphy, vol. 27, no. 4, pp. 340-347, 2003.

[3] C. N. Zou, S. H. Xue, W. Z. Zhao et al., "Depositional sequences and forming conditions of the Cretaceous stratigraphic lithologic reservoirs in the Quantou-Nengjiang Formations, South Songliao Basin," Petroleum Exploration and Development, vol. 31, no. 2, pp. 16-19, 2004.

[4] Y. Wang, Y.-M. Wang, Z.-K. Zhao et al., "Origin and evolution of the west slope belt in Member 4 of Quantou Formation to Yaojia Formation, South Songliao Basin," Petroleum Exploration and Development, vol. 32, no. 3, pp. 33-90, 2005.

[5] H. W. Deng, H. B. Wu, N. Wang, and A. C. Timothy, "Division of fluvial sequence stratigraphy: an example from the lower cretaceous Fuyu oil-bearing layer, the Songliao Basin," Oil \& Gas Geology, vol. 28, no. 5, pp. 621-627, 2007.

[6] C. L. Li, J. Xie, P. P. Chen, Z. L. Fan, and Z. Q. Sun, "Highresolution sequence stratigraphy model of the delta system in Daqingzijing area, JiLin Province," Journal of Stratigraphy, vol. 38, no. 3, pp. 355-362, 2014.

[7] Z.-S. Wei, X.-M. Song, Z.-X. Tang, X. Chu, and G. Yang, "Sedimentary facies and lithologic oil pools of the Upper Cretaceous Qingshankou Formation in Daqingzijing area, Changling Sag, southern Songliao Basin," Petroleum Exploration and Development, vol. 43, no. 1, pp. 28-33, 2007.

[8] M. D. Yang, M. H. Yang, Z. X. Tang, Y. H. Wang, X. Chu, and J. F. Wang, "Analysis of hydrocarbon distribution in Daqingzijing area of the Southen Songliao Basin," Petroleum Geology and Experiment, vol. 25, no. 3, pp. 252-256, 2003.

[9] J. G. Wang, T. Q. Wang, P. S. Wei et al., "Identification of uncomformity plane at the bottom of Qingsan Member in the Songliao Basin and its implication for petroleum geology," Acta Geologica Sinica, vol. 83, no. 1, pp. 79-88, 2009.

[10] Y. J. Zhao, Z. D. Bao, J. Fu, Z. Q. Wang, Z. M. Liu, and H. Zhao, "Control of hydrocarbon migration and accumulation processes in the low-contrast reservoir," Geological Science and Technology Information, vol. 29, no. 2, pp. 71-76, 2010.

[11] G. M. Hamada, M. S. Al-Blehed, M. N. Al-Awad, and M. A. AlSaddique, "Petrophysical evaluation of low-resistivity sandstone reservoirs with nuclear magnetic resonance log," Journal of Petroleum Science and Engineering, vol. 29, no. 2, pp. 129-138, 2001.

[12] A. Cerepi, C. Durand, and E. Brosse, "Pore microgeometry analysis in low-resistivity sandstone reservoirs," Journal of Petroleum Science and Engineering, vol. 35, no. 3-4, pp. 205-232, 2002.

[13] C.-M. Yang, C.-C. Zhou, and X.-Z. Cheng, "Origin of low resistivity pays and forecasting of favorable prospecting areas," Petroleum Exploration and Development, vol. 35, no. 5, pp. 600-605, 2008.

[14] L. Yan, S.-Q. Tan, B.-Z. Pan, P. Zhang, and Y.-M. Liu, "Genetic mechanism and logging evaluation method for low resistivity reservoirs: Taking Guantao Formation of Gangbei area for instance," Journal of Jilin University (Earth Science Edition), vol. 40, no. 6, pp. 1456-1462, 2010.

[15] V. I. Isaev, G. A. Lobova, and E. N. Osipova, "The oil and gas contents of the Lower Jurassic and Achimovka reservoirs of the Nyurol'ka megadepression," Russian Geology and Geophysics, vol. 55, no. 12, pp. 1418-1428, 2014.

[16] V. Mashaba and W. Altermann, "Calculation of water saturation in low resistivity gas reservoirs and pay-zones of the Cretaceous Grudja Formation, onshore Mozambique basin," Marine and Petroleum Geology, vol. 67, pp. 249-261, 2015.

[17] P. J. Wang, X. D. Du, J. Wang, and D. P. Wang, "The chronostratigraphy and stratigraphic classification of the Cretaceous of the Songliao Basin," Acta Geologica Sinica, vol. 69, no. 4, pp. 372-381, 1995.

[18] F.-X. Gong, Y.-H. Shan, G. Lin, Z.-A. Li, and S.-L. Liu, "Mechanism of early post-rift normal faults in the central Songliao basin, northeastern China," Earth Science Journal of China University of Geosciences, vol. 33, no. 4, pp. 547-554, 2008.

[19] R. F. Ge, Q. L. Zhang, L. S. Wang, and G. A. Xie, "Tectonic Evolution of Songliao basin and the prominent tectonic regime transition in eastern China," Geological Review, vol. 56, no. 2, pp. 181-195, 2010. 
[20] J.-Z. Li, T. Yang, L.-W. Wang, and T. Jiang, "Fault structure and its controlling role to hydrocarbon accumulation in Daqingzijing area, Southern Songliao Basin," Petroleum Exploration and Development, vol. 31, no. 1, pp. 18-20, 2004.

[21] Z. J. Liu, P. C. Sun, R. Liu, Q. T. Meng, Y. Y. Bai, and Y. B. $\mathrm{Xu}$, "Research on geological conditions of shale ccoexistent energy mineralization (accumulation): take the Qingshankou Formation in Upper Cretaceous, Songliao Basin for example," Acta Sedimentologica Sinica, vol. 32, no. 3, pp. 593-600, 2014.

[22] W. W. Givens, "A conductive rock matrix model (CRMM) for the analysis of low-contrast resistivity formations," The Log Analyst, vol. 28, no. 2, pp. 138-151, 1987.

[23] T. Han, M. B. Clennell, and M. Pervukhina, "Modelling the low-frequency electrical properties of pyrite-bearing reservoir sandstones," Marine and Petroleum Geology, vol. 68, pp. 341-351, 2015.

[24] X. Y. Zhao, L. B. Zeng, Z. Q. Liu et al., "Characteristics of calcareous interbeds and their impact on distribution of natural fractures in tight sandstone reservoirs," Geological Review, vol. 61, no. 1, pp. 163-171, 2015.

[25] Y. J. Wang, X. M. Song, L. P. He, N. X. Chen, and H. W. Yu, "Geologic origin of low-resistivity layers in deep reservoir of Gaoshangpu Oilfield," Acta Petrolei Sinica, vol. 31, no. 3, pp. 426431, 2010.

[26] J.-L. Wu, J.-M. Sun, J.-J. Zhu, S.-C. Geng, Z.-C. Li, and Y.C. Zhang, "Study on macro-geologic control genesis of microgeological causes in low-resistivity oil layer of Jiyang depression," Journal of China University of Petroleum: Edition of Natural Science, vol. 30, no. 3, pp. 22-25, 2006.

[27] Z. L. Huang, X. G. Pu, C. N. Liang, and Z. P. Wei, "Characteristics and formation mechanism of low-resistivity reservoirs in the Southern Songliao Basin," Natural Gas Industry, vol. 26, no. 8, pp. 27-30, 2006.

[28] H. H. Yu, H. Q. Li, B. Guo, H. T. Sun, and H. X. Zhang, "Low-resistivity oil layers fine evaluation approaches based on mechanism," Journal of Jilin University (Earth Science Edition), vol. 42, no. 2, pp. 335-343, 2012.

[29] Q.-H. Chen, S.-P. Sun, and Q. Li, "Genetic analysis on lowresistive formation of Dongying Formation in Gudong Oilfield," Journal of China University of Petroleum: Edition of Natural Science, vol. 28, no. 3, pp. 9-12, 2004.

[30] J. M. Sun, K. W. Wang, and J. J. Zhu, "Microcosmic influence factor for electrical properties of low-resistivity reservoir in Jiyang Depression," Acta Petrolei Sinica, vol. 27, no. 5, pp. 61-65, 2006. 

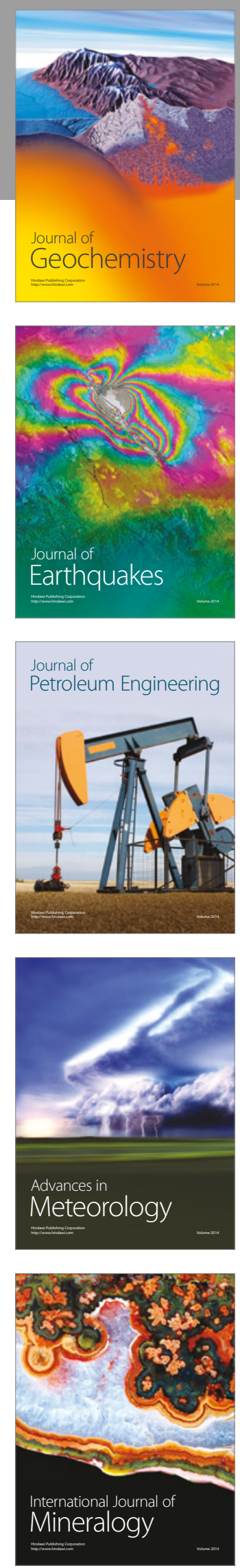
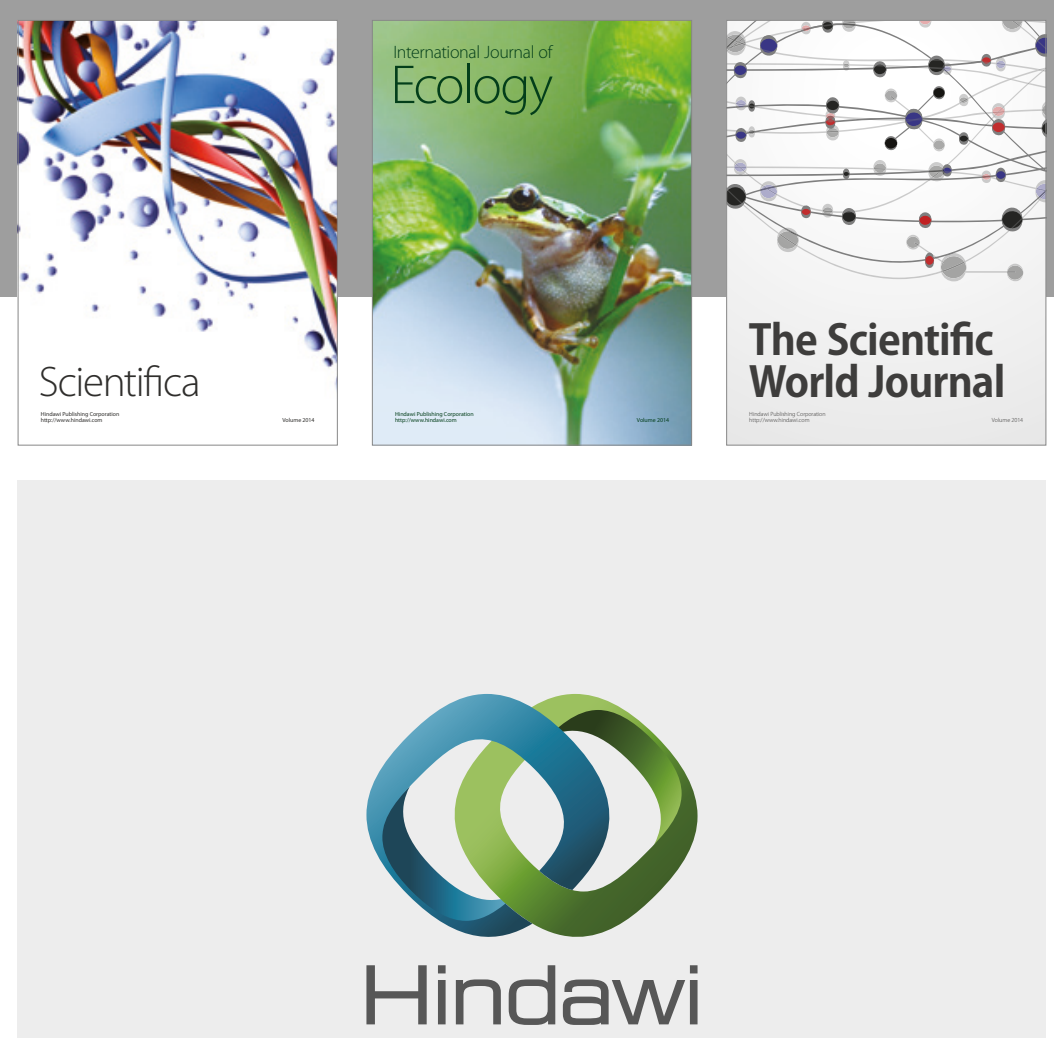

Submit your manuscripts at

https://www.hindawi.com
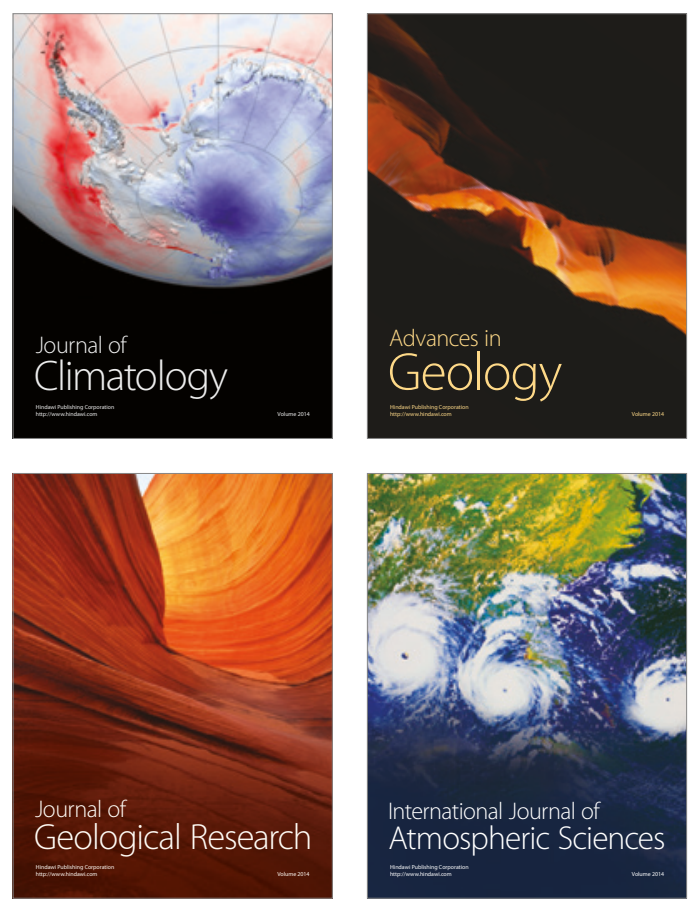

The Scientific

World Journal
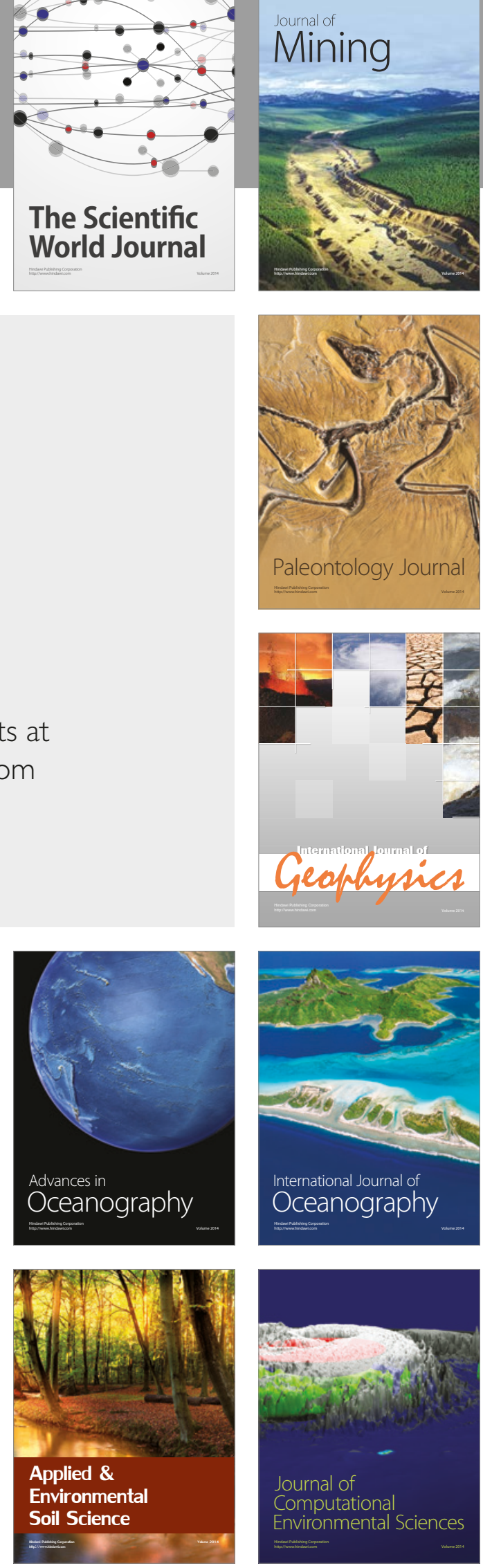